\title{
GENETIC DIVERSITY HAS PREVAILED, NOT THE MASTER RACE
}

\author{
FERID MURAD
}

Genetic heterogeneity and diversity have prevailed as primitive tribes migrated throughout the world and adapted to their environment. The Nazi plans for the "Master Super Race" were obviously flawed from the start, scientifically as well as morally. We have learned from history and science that inbred families have a greater incidence of genetic disorders. This has been well documented with some of the royal families in the world with marriages between family members. Today we can witness a similar phenomenon with Pima Indians in Southern Arizona. With sedentary life style, excess calories and alcohol, and intratribal marriages, the incidence of a complex genetic disorder, diabetes mellitus, can be as great as 50-70 percent in some families. There are undoubtedly many other examples.

Personally, I believe that the diverse groups of immigrants to the United States in the past 200 years have resulted in a remarkably heterogeneous genetic pool. This heterogeneity and the resulting mixed marriages between individuals from diverse countries and genetic backgrounds and the work ethic they have inherited have been major factors in the productivity, strength, and creativity of this country.

As an example, since 1901 there have been a total of 743 Nobel Laureates in Chemistry, Physics, Medicine, Peace, and Literature and 58 in Economics. Since World War II, more than half of the Laureates in Science (Physics, Chemistry, and Medicine) have been U.S. citizens or residents. Even more interesting, many of these have been immigrants or offspring of Jewish families from Eastern Europe who relocated because of the Holocaust.

Hitler's Plan for the Master Super Race was terribly flawed from the start. It resulted in the unfortunate death of millions. Furthermore, Germany and Eastern Europe lost some of their most talented people to the United States and other countries to compliment the gene pool elsewhere. 